\section{Effect of Grinding and Resintering on the Fatigue Limit and Surface Characterization of a Y-TZP Ceramic}

\author{
Gabriela Scatimburgo Polli ${ }^{1}$, Gabriel Rodrigues Hatanaka ${ }^{1}$, Filipe de Oliveira \\ Abi-Rached ${ }^{1}$, Lígia Antunes Pereira Pinelli ${ }^{1}$, Márcio de Sousa Góes², Paulo \\ Francisco Cesar ${ }^{3}$, José Maurício dos Santos Nunes Reis ${ }^{1}$
}

\begin{abstract}
This study evaluated the effect of grinding protocols and resintering on flexural fatigue limit and surface characterization of Lava TM Y-TZP. Bar-shaped specimens $(20 \times 4.0 \times 1.2$ $\mathrm{mm}, \mathrm{n}=40 ; 20 \times 4.0 \times 1.5 \mathrm{~mm}, \mathrm{n}=80)$ were obtained. Half of the thinner specimens $(1.2$ $\mathrm{mm}$ ) constituted the as-sintered group (AS), while the thicker ones $(1.5 \mathrm{~mm})$ were ground with diamond burs under irrigation (WG) or not $(\mathrm{G})$. The other half of thinner and half of ground specimens were resintered $\left(1000{ }^{\circ} \mathrm{C}\right.$, $\left.30 \mathrm{~min}\right)$, forming the groups ASR, WGR and GR. Fatigue limit $(500,000$ cycles, $10 \mathrm{~Hz})$ was evaluated by staircase method in a 4-point flexural fixture. Data were analyzed by 2 -way ANOVA and Tukey's test $(\alpha=0.05)$. Surface topography $(n=3)$ and fracture area $(n=3)$ were evaluated by SEM. X-ray diffraction data $(n=1)$ was analyzed by Rietveld refinement. ANOVA revealed significant differences $(p<0.001)$ for the grinding protocol, resintering and their interaction. Grinding increased the fatigue limit of non-resintered groups. There was no significant difference among the resintered groups. Resintering significantly increased the fatigue limit of the AS group only. Both protocols created evident grooves on zirconia surface. The failures initiated at the tensile side of all specimens. The percentages (wt $\%$ ) of monoclinic phase were AS (8.6), ASR (1.2), G (1.8), GR (0.0), WG (8.2), WGR (0.0) before, and AS (7.4), ASR (6.5), G (3.2), GR (0.2), WG (4.6), WGR (1.1) after cyclic loading. Grinding increased the fatigue limit of non-resintered Y-TZP and formed evident grooves on its surface. Resintering provided significant increase in the fatigue limit of as-sintered specimens. In general, grinding and resintering decreased or zeroed the monoclinic phase.
\end{abstract}

\author{
'Department of Dental Materials and \\ Prosthodontics, Araraquara Dental \\ School, UNESP - Univ Estadual \\ Paulista, Araraquara, SP, Brazil \\ ${ }^{2}$ UNILA - Universidade Federal \\ da Integração Latino-Americana, \\ Foz do lguaçu, PR, Brazil \\ ${ }^{3}$ Department of Biomaterials \\ and Oral Biology, Dental School, \\ USP - Universidade de São \\ Paulo, São Paulo, SP, Brazil
}

Correspondence: José Maurício dos Santos Nunes Reis, Rua Humaitá, 1680, Centro, 14801-903 Araraquara, SP, Brasil. Tel: +55-16-3301-6503. e-mail: reis@foar.unesp.br

\begin{abstract}
Key Words: zirconia, fatigue limit, staircase method, grinding, resintering.
\end{abstract}

\section{Introduction}

The yttria partially stabilized tetragonal zirconia polycrystalline (Y-TZP) is widely used in dental practice, mainly for manufacturing metal-free frameworks for single units and long span fixed dental and implantsupported prostheses. However, mechanical and thermal aging may induce tetragonal $(\mathrm{t})$ to monoclinic $(\mathrm{m})$ phase transformation (toughening mechanism) that may modify the mechanical behavior of the zirconia $(1,2)$.

Zirconia frameworks/implant abutments are usually designed and milled in computer-aided design/computeraided manufacturing (CAD/CAM) systems with minimal excess in the finishing line of tooth/abutment preparation. After sintering, this excess is finished in the lab by grinding on individual dies. Clinical grinding may also be required to obtain enough interocclusal space for the veneering porcelain, accurate marginal fit, as well as to correct the emergence profile, and the design of frameworks and implant abutments. A minimal or an extensive redesign is defined by several factors, like virtual 3D project of the framework, precision milling of CAD/CAM systems and the shape of tooth preparation (3). According to Swain (4), the effect of grinding on the flexural strength of zirconia is contradictory and influenced by its severity and the attained local temperature, as well as by the amount, size and depth of the flaws/grooves, which are strongly related to the volume of $t \rightarrow m$ transformation.

Despite the possibility of toughening mechanism, Iserı et al. (5) did not find significant differences on the flexural strength of a Y-TZP submitted to different grinding methods. In turn, Luthardt et al. (6) recommend that grinding should be carefully performed ensuring higher zirconia reliability. Similarly, Denry and Holloway (7) suggested that grinding could damage the longitudinal mechanical strength of Y-TZP. Nevertheless, heat treatment ("resintering") after grinding may be beneficial by the reverse phase transformation $(\mathrm{m} \rightarrow \mathrm{t})$ and elimination of the compressive stress at the zirconia surface (7). The consequence of this phenomenon occurs according to the severity of condition to which the material is subjected and related to the amount of flaws/cracks. The $m \rightarrow t$ transformation may improve the aging resistance (1) and, consequently, the reliability of the zirconia (8). On the other hand, its influence on the mechanical behavior of Y-TZP has been scarcely investigated (9).

Although several studies $(3,5-9)$ evaluated the 
consequences of grinding, finishing, polishing and sandblasting on the mechanical properties of Y-TZP, very little is known about the influence of grinding and resintering treatments on its fatigue limit. A widely used method that has proven to be suitable for evaluating the zirconia fatigue limit is the staircase approach (10-15). Mechanical fatigue tests are usually performed to analyze the effect of aging on several restorative materials and often only analyze the ability of materials to resist a given number of cycles. The staircase approach is an outstanding method for estimating the fatigue behavior, investigating the survival rates and for calculating the maximum stress supported by a material in cyclic conditions (16). The threshold level is calculated from an up-and-down test condition, in which the specimens are repeatedly cycled under different stresses until a given number of runouts and failures have been reached. In addition, the staircase method requires fewer tests to calculate reliable threshold values than any other cycling method, because it concentrates testing near the mean (11).

Zirconia under mechanical stress may undergo changes in its toughening mechanism, favoring a subcritical propagation of microcracks and the low-temperature degradation phenomenon (17). Thus, its long-term stability and fatigue properties should be studied warranting safe therapeutic procedures. Therefore, it is important to evaluate the effect of resintering (regeneration firing) and different grinding protocols on the fatigue limit of Y-TZP, as well as on its surface characteristics (topography and phase transformation). The null hypothesis was that grinding and resintering would not influence the Y-TZP fatigue limit.

\section{Material and Methods}

\section{Preparation of Zirconia Specimens}

Pre-sintered CAD/CAM zirconia milling blocks (Lava Frame; 3M ESPE AG, Seefeld, Germany) were cut into bars of $25 \times 5.0 \times 1.5 \mathrm{~mm}(\mathrm{n}=40)$ and $25 \times 5.0 \times 1.9 \mathrm{~mm}(\mathrm{n}=80)$ using a water-cooled diamond disc (Diamond Wafering Blade, Series 15LC Diamond \#11-4276; Buehler Ltd, Lake Bluff, II, USA) by a high-precision saw (Isomet 1000; Buehler Ltd). The zirconia bars were washed in tap water and their edges were carefully finished using a ceramic polisher (Exa Cerapol 0361HP; Edenta AG, Au, Switzerland) in a low-speed hand piece.

The sintering process was performed in Lava Furnace 200 (Dekema Dental-Keramiköfen GmbH, Freilassing, Germany), according to the manufacturer's recommendations (heating rate $=20^{\circ} \mathrm{C} / \mathrm{min}$ : $0-1000{ }^{\circ} \mathrm{C} ; 10{ }^{\circ} \mathrm{C} / \mathrm{min}$ : $1000-1500{ }^{\circ} \mathrm{C}$; holding time $=2.0 \mathrm{~h}$ and cooling rate $=15^{\circ} \mathrm{C} / \mathrm{min}: 1500-$ $800{ }^{\circ} \mathrm{C} ; 20^{\circ} \mathrm{C} / \min$ : $800-250{ }^{\circ} \mathrm{C}$, when oven was opened). The dimensions of the zirconia bars after sintering shrinkage were $20 \times 4.0 \times 1.2 \mathrm{~mm}(\mathrm{n}=40)$ and $20 \times 4.0 \times 1.5 \mathrm{~mm}(\mathrm{n}=80)$.

\section{Grinding Procedures}

Half of the thinner specimens constituted the assintered group (AS - control). The thicker ones were ground under constant irrigation in distilled water (WG) or not (G). For this procedure, the specimens were positioned into a custom-made stainless steel apparatus with a rectangular central opening $(20.05 \times 4.05 \times 1.20 \mathrm{~mm})$ and the $0.3 \mathrm{~mm}$ excess of zirconia was ground with $151 \mu \mathrm{m}$-grit cylindrical diamond burs (4ZR; Komet-Brasseler, Lemgo, Germany) in a high-speed hand piece (Kavo Extra Torque 605, Kavo do Brasil Ind. e Com. Ltda, Joinville, SC, Brazil) at 350,000 rpm, until the final thickness of $1.2 \mathrm{~mm}$, measured by a digital caliper (500-144B; Mitutoyo Sul Americana, Suzano, SP, Brazil) in four different points. The high-speed handpiece was clamped to a holding arm, which moved horizontally, assuring the application of a constant load of the diamond bur in contact with the specimen surface and perpendicular to its length. After grinding, all zirconia bars $(20 \times 4.0 \times 1.2$ $\mathrm{mm}$ - ISO 6872 standard) (18) were washed in tap water and left to dry at room temperature for $24 \mathrm{~h}$.

\section{Resintering (Regeneration Firing)}

The other half of the thinner specimens and half of the WG and $G$ groups were submitted to a resintering treatment $\left(1000{ }^{\circ} \mathrm{C}\right.$ for $30 \mathrm{~min}$ ) in a conventional porcelain oven (Aluminipress; EDG Equipamentos e Controles Ltda, São Carlos, SP, Brazil), according to the Lava ${ }^{\mathrm{TM}}$ manufacturer's recommendation, resulting in ASR, WGR and GR groups $(n=20)$. After this procedure, the specimens were cooled to room temperature by opening the oven door.

\section{Cyclic Fatigue Testing (Staircase Method)}

For determining the entry fatigue stress level, it was necessary to perform monotonic tests before the cyclic fatigue testing. For each designed experimental condition (AS, WG, G, ASR, WGR and GR), 12 additional specimens $(20 \times 4.0 \times 1.2 \mathrm{~mm})$ were used to measure the monotonic four-point ultimate flexural strength in a servo-hydraulic mechanical testing machine (810 Material Test System; MTS Systems Corp, Eden Prairie, MN, USA) with a $10 \mathrm{kN}$ load cell and a constant crosshead speed of $0.5 \mathrm{~mm} / \mathrm{min}$ (ISO 6872) (18). The specimens were positioned in a fourpoint flexural fixture (16-mm span) over two $0.8-\mathrm{mm}$ radius rounded bearers in artificial saliva, thermostatically maintained at $37 \pm 1^{\circ} \mathrm{C}$. A uniaxial compressive force was applied over the non-ground surface of each specimen by two-round loading pistons $(0.8 \mathrm{~mm}$-radius, $8.0 \mathrm{~mm}$ distance), the ground surfaces being loaded in tension until failure. The ultimate flexural strength was recorded in Newton $(\mathrm{N})$ and calculated in MPa using the equation listed in ISO 6872 (18). 
Twenty specimens of each group were positioned in the MTS 810 testing machine, under the same conditions as for the monotonic flexural strength test, and subjected to a cyclic load in a four-point bending mode at $10 \mathrm{~Hz}$ frequency (19), for 500,000 cycles in artificial saliva at $37 \pm 1.0^{\circ} \mathrm{C}$. Cyclic fatigue test was determined by the staircase method (20). According to Collins (20), a minimum of 15 specimens is required for accurate data analysis by staircase. The entry fatigue stress level was set at $60 \%$ of the monotonic stress at failure, which was increased or decreased by a fixed increment ( $4.0 \%$ of mean flexural strength values) $(16,21)$, depending on the occurred event (failure or survival) during the application of 500,000 cycles. If the specimen survived to 500,000 cycles of loading, a stress level one increment higher was applied to the next specimen. If the specimen fractured in fewer than 500,000 cycles of loading, a load one increment lower was applied to the next one. This procedure was performed until all specimens of each group were expended. The data analysis was based on the least frequent event (failure vs. survival).

The mean fatigue limit values $(\mathrm{XL})$ and standard deviations (SD) were calculated using the following equations (16):

$$
\begin{aligned}
& X L=X_{0}+d(A / N) \pm 0.5\{1\} \\
& S D=1.62 d[N B-(A 2 / N 2)+0.029]\{2\},
\end{aligned}
$$

where $X_{0}$ is the lowest recorded failure stress (MPa), $\mathrm{d}$ is the fixed increment in MPa, $\mathrm{N}$ is the sum of failures or survivals occurring at the different stress levels, independent of the load applied, A is the total sum of failures or survivals, multiplied by the stress levels and $B$ is the total sum of failures or survivals, multiplied by the square of the stress levels. In the first equation, a negative sign was used when the analysis was based on failures, in other words, when they occurred in lower number within the 20 specimens evaluated for each experimental group.

\section{Statistical Analysis}

Data from cyclic fatigue tests were statistically analyzed by 2 -way analysis of variance, considering the grinding protocol and resintering as independent variables (Microsoft ${ }^{\oplus}$ Excel for Mac 2011, version 14.4.7, Microsoft Corporation, Redmond, WA, USA). If there was a significant effect, the Tukey's post-hoc Honestly Significant Difference (HSD) test ( $\alpha=0.05$ ) was applied.

\section{Surface Characterization (Topography and Phase Transformation)}

For the analyses of surface topography and phase transformation, all specimens were ultrasonically cleaned in $99 \%$ isopropanol for $10 \mathrm{~min}$ and dried in silica gel desiccator for $24 \mathrm{~h}$.

\section{Surface Topography Analysis}

The non-fractured cycled specimens $(n=3)$ of each experimental group were randomly selected, goldsputtered, mounted on metallic stubs and their tensile sides were examined by scanning electron microscope (SEM - JSM-6510LV; JEOL Ltd., Peabody, MA, USA) at $\times 500$ magnification with a $12 \mathrm{kV}$ accelerating voltage. Non-cycled additional specimens of the groups AS and ASR were also characterized $(n=3)$ to evaluate the effect of cyclic loading on the zirconia topography without grinding influence.

In order to determine the origin of the failures, the fractured surfaces of three cycled specimens from each group were examined by SEM at $\times 30$ magnification.

\section{Surface Phase Transformation Analysis}

The X-ray diffraction (XRD) analysis assessed the effect of the grinding with or without cooling and the resintering on the phase transformations of Y-TZP. The XRD data $(n=1)$ were collected using a RIGAKU ${ }^{\circledR}$ RINT2000 rotating anode diffractometer ( $40 \mathrm{kV}, 70 \mathrm{~mA})$ with $\mathrm{Cu} \mathrm{k} \alpha$ radiation $(\lambda k \alpha 1=1.5405 \AA, \lambda k \alpha 2=1.5443 \AA$, $\mid k \alpha 1 / l k \alpha 2=0.5)$ monochromatized by a curved graphite crystal. An interval from $20^{\circ}$ to $120^{\circ}(2 \theta)$, with a step size of $0.02^{\circ}(2 \theta), 4 \mathrm{~s}$ per step and divergence 0.5 , and open receiving slits were the selected conditions for Rietveld refinement (22). The Rietveld refinements were performed using the General Structure Analysis System (GSAS) program suite with EXPGUI interface. The following parameters were refined: atomic coordinates, occupancies, unit cell, scale factor, sample displacement, atomic displacement and full width at half maximum (FWHM). The crystal structure parameter used as basis of the ICSD (Inorganic Crystal Structure Database) code was: 66781 ( $\mathrm{ZrO}_{2}$, tetragonal), $18190\left(\mathrm{ZrO}_{2}\right.$, monoclinic) and 53998 ( $\mathrm{ZrO}_{2}$, cubic).

\section{Results}

\section{Flexural Strength Fatigue Limit}

The 2-way analysis of variance revealed significant effect $(p<0.001)$ on the flexural strength fatigue limit for the variables grinding protocol, resintering and their interaction. The mean flexural strength fatigue limit values, standard deviations and the results of Tukey's HSD posthoc test are presented in Table 1. The AS group presented the lowest mean flexural strength fatigue limit $(p<0.05)$, which was increased by the resintering procedure, showing no significant difference among the ground groups.

\section{Surface Topography}

Representative SEM micrographs of cycled and noncycled groups are presented in Figure 1. The ground specimens (WG and $G$ ) produced evident changes on the 
surface feature, compatible with hazards created by the diamond bur (Figs. 1C and 1E). Resintering did not produce changes in the zirconia surface topography (Figs. 1A vs. $1 \mathrm{~B} ; 1 \mathrm{C}$ vs. $1 \mathrm{D}$ and $1 \mathrm{E}$ vs. 1F). Similarly, no apparent surface changes were observed comparing the cycled with the non-cycled specimens, with minimal flaws noted in both (Figs. 1A and 1G). Regardless of the experimental groups, examination of the fracture sites revealed that all failures initiated at the tensile side of the specimens (Fig. 2).

\section{Surface Phase Transformation}

Table 2 shows the results of quantitative phase analysis and Figure 3 presents the representative diffraction patterns of the experimental groups. In general, before and after cyclic loading, the grinding with or without cooling provided a decrease in the monoclinic phase, and a "decomposition" of $\mathrm{t}-\mathrm{ZrO}_{2}, \mathrm{~m}-\mathrm{ZrO}_{2}$ and $\mathrm{c}-\mathrm{ZrO}_{2}$ phases in other $\left(\mathrm{t}-\mathrm{ZrO}_{2}{ }^{*}\right)$. For the $\mathrm{G}$ and $\mathrm{WG}$ non-cycled groups, the resintering promoted total incorporation of monoclinic phase into tetragonal phase. For the other experimental conditions, this procedure decreased the monoclinic phase content.

\section{Discussion}

Although the CAD/CAM technology allows obtaining accurate metal-free prostheses, adjustments in zirconia frameworks/implant abutments are routinely performed in laboratory and clinical practice $(8,9,23)$. Several authors $(9,19,24)$ have claimed that these adjustments and surface treatments may modify significantly the physical, chemical and mechanical properties, influencing the strength of the Y-TZP with different degrees of damage $(3,10)$.

This study revealed that grinding increased the flexural fatigue limit of the Lava ${ }^{\mathrm{TM}}$ zirconia, regardless of watercooling. Pereira et al. (15) also observed an increase in the fatigue limit of two Y-TZP ceramics after grinding with coarse diamond bur $(181 \mu \mathrm{m})$. Probably, this finding is related to a "decomposition" of $\mathrm{t}-\mathrm{ZrO}_{2}, \mathrm{~m}-\mathrm{ZrO}_{2}$ and $\mathrm{c}-\mathrm{ZrO}_{2}$ phases in another tetragonal $\left(\mathrm{t}-\mathrm{ZrO}_{2}{ }^{*}\right.$; see Table 2) phase. Therefore, in the ground groups it can be observed

Table 1. Mean flexural strength fatigue limit values (MPa) and standard deviations $( \pm)$ of the experimental groups

\begin{tabular}{lcc}
\hline Group & Non-resintered & Resintered (R) \\
\hline As-sintered (AS) & $448.55( \pm 56.22) \mathrm{B}^{\mathrm{b}}$ & $550.49( \pm 42.33) \mathrm{A}^{\mathrm{a}}$ \\
$\begin{array}{l}\text { Grinding (G) } \\
\begin{array}{l}\text { Water-cooled } \\
\text { grinding (WG) }\end{array}\end{array} 520.92( \pm 34.95) \mathrm{A}^{\mathrm{a}}$ & $557.65( \pm 59.78) \mathrm{A}^{\mathrm{a}}$ \\
\hline
\end{tabular}

Vertically, entries with the same capital letter, and horizontally, entries with the same superscript letter, were not statistically different $(p \geq 0.05)$. the prevalence of the tetragonal phase in relation to the monoclinic one, as observed by Denry and Holloway (7). According to Mochales et al. (25), the higher monoclinic phase content impairs the mechanical behavior of zirconia along time, making it critically brittle. Considering that in the present study was simulated a long-term clinical condition, it may be inferred that the higher percentage of tetragonal phase was probably responsible for the best mechanical performance of the ground specimens. Other hypothesis could be related to a molecular rearrangement induced by grinding, which may have altered the physicochemical structure of the material, increasing its mechanical strength. Zirconia grains are not rigid and their three-dimensional movement makes deformation easier after a switching event (26). Maybe the $m \rightarrow t$ transformation induced by heat during the grinding (27) was masked by the effect of "decomposition" of phases and/or molecular rearrangement induced by grinding. Water-cooling has been used as an aid to the grinding process of Y-TZP surface, cleaning off debris and avoiding overheating with possible phase transformation consequences (3). In this study, before and after cycling, uncooled or cooled grinding provided a decrease in the monoclinic phase and enhanced the mechanical strength of Y-TZP. Further studies are required for a better understanding of how grinding can change the atomic/molecular structure, influencing the zirconia strength. Despite these positive results observed for the evaluated mechanical property, creation of microcracks by grinding can make the zirconia more

Table 2. Phase content (wt\%) of the experimental groups

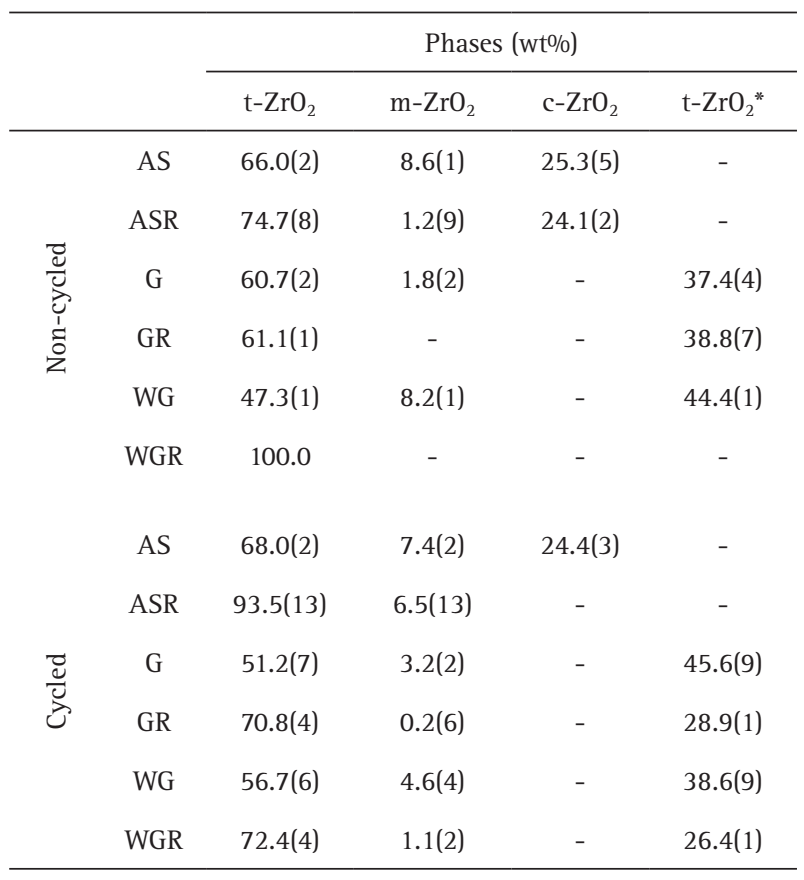

t: tetragonal; m: monoclinic; c: cubic. 
susceptible to degradation in aqueous or acid environment $(2,8,19)$. Moisture can strongly exacerbate fatigue crack propagation, with slow growth from its nucleation points $(2,10,23,24)$.
Cyclic loads lead to stresses that initiate the propagation of subcritical cracks along the surface of material, which may contribute to its failure $(10,13)$. The nucleation sites and propagation of cracks usually appear near the site
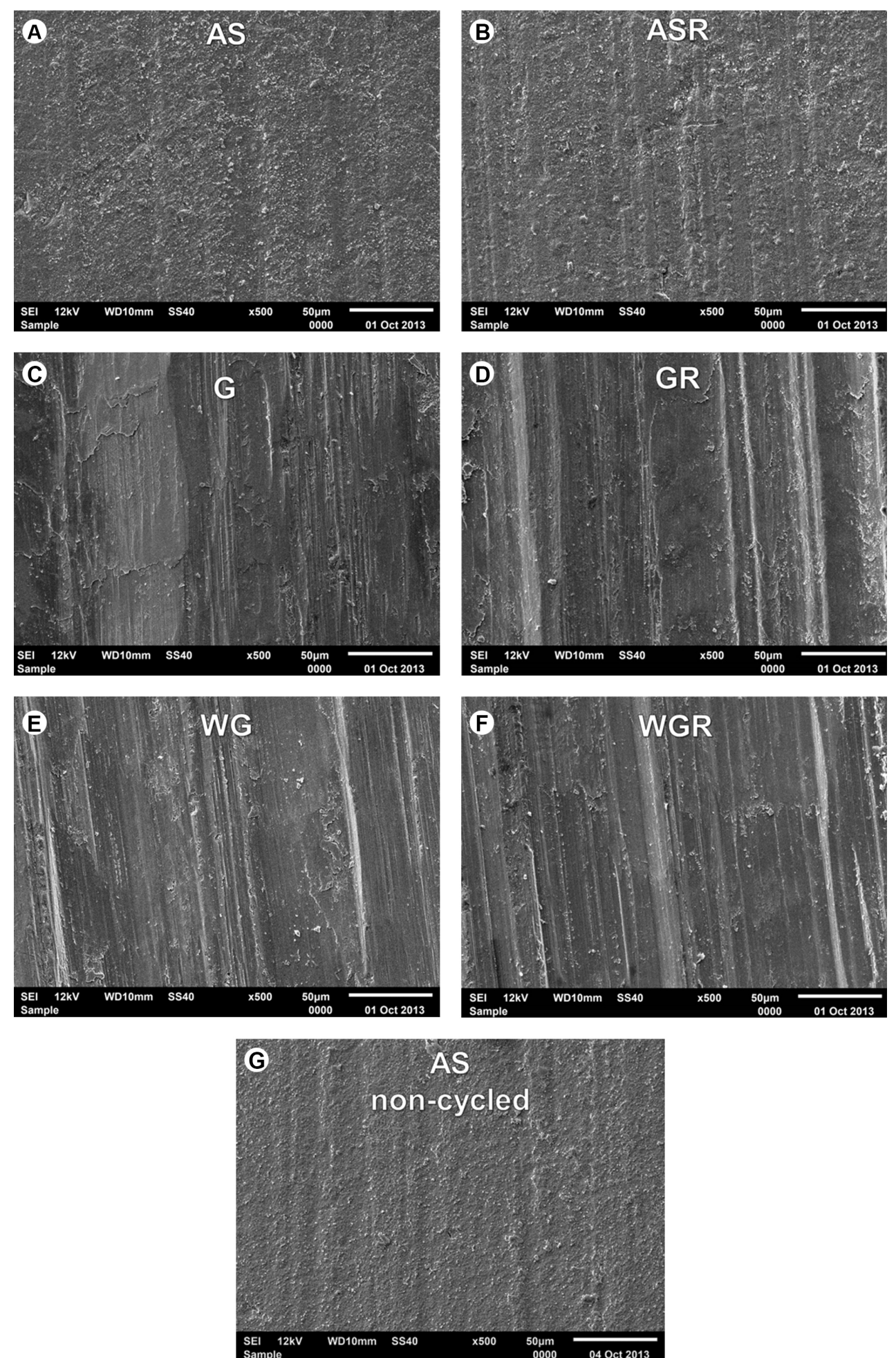

Figure 1. Representative SEM micrographs of cycled (A-F) and non-cycled (G) groups. A: as-sintered specimen; B: resintered as-sintered specimen; C: ground specimen without cooling; D: resintered ground specimen without cooling; E: ground specimen with cooling; F: resintered ground specimen with cooling; G: as-sintered specimen. 
of load application, in the tensile region $(10,13,23)$. Due to repetitive loads during chewing, small defects tend to increase until a critical size, in which catastrophic failures frequently occur (8). Deep surface defects may act as stress concentration areas, being a strength-limiting factor if the length of the flaw extends beyond the superficial compression layer $(15-20 \mu \mathrm{m})$ on the material's surface $(5-7,10)$. In this study, cyclic loading appears not to have changed the surface topography of the samples. In Figures $1 \mathrm{~A}$ and $1 \mathrm{G}$, non-detectable differences can be observed

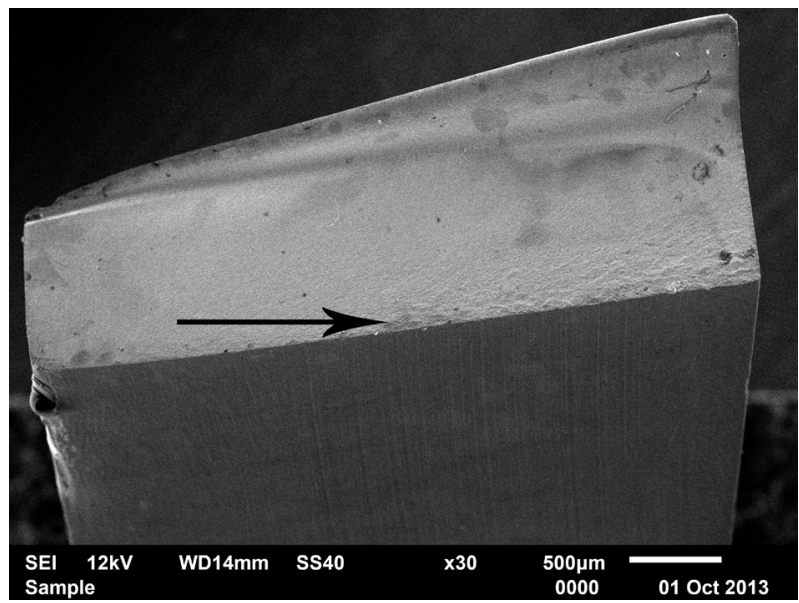

Figure 2. SEM micrograph illustrating the fractured surface of a nonresintered control group specimen. The arrow indicates the beginning of fracture in tensile side. Delamination failure may be seen at the opposite side (compressive area).

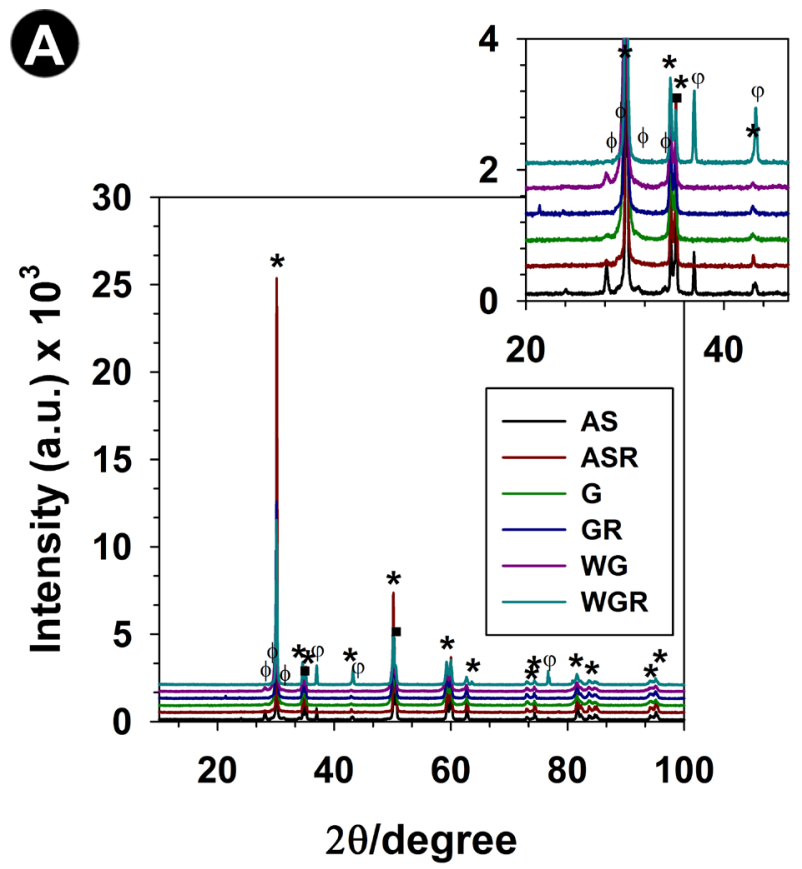

between cycled and non-cycled surfaces. This observation may be possibly attributed to the high elasticity modulus of zirconia and its low deflection under flexural cyclic loading. Thus, the mechanical fatigue appears to be not enough to change or damage the topography of the zirconia bars. Similar findings were reported by Amaral et al. (13), in which no signs of crack growth were observed on the surface of a Y-TZP ceramic after a high number of cycles. Further analyzes other than SEM evaluation must be performed to confirm these observations. As expected, the grinding produced apparent changes in the characteristics of the surface. Grinding procedures usually produce grooves, microcracks or even cracks, depending on the used grain of the bur, load and speed $(5,10,23,27)$. The mechanism by which surface damages occur after phase transformation may be explained by the grain loss associated with the increase in the volume of the crystalline material (7). Guazzato et al. (27) showed that coarse grinding (125-150 $\mu \mathrm{m})$ leads to an increased surface roughness, resulting in reduced bending resistance of Y-TZP. Conversely, the coarsegrit $(151 \mu \mathrm{m})$ burs used in the present study increased the fatigue limit of Y-TZP. Based on these results, it may be inferred that the cracks did not present a significant critical size to detrimentally affect the fatigue strength of Lava ${ }^{\mathrm{TM}}$ Y-TZP. On the other hand, these microcracks may promote degradation of the material in the oral environment and may cause deterioration of its long-term strength (23).

In this study, a reverse phase transformation $(\mathrm{m} \rightarrow \mathrm{t})$ occurred after resintering. This phenomenon is accompanied

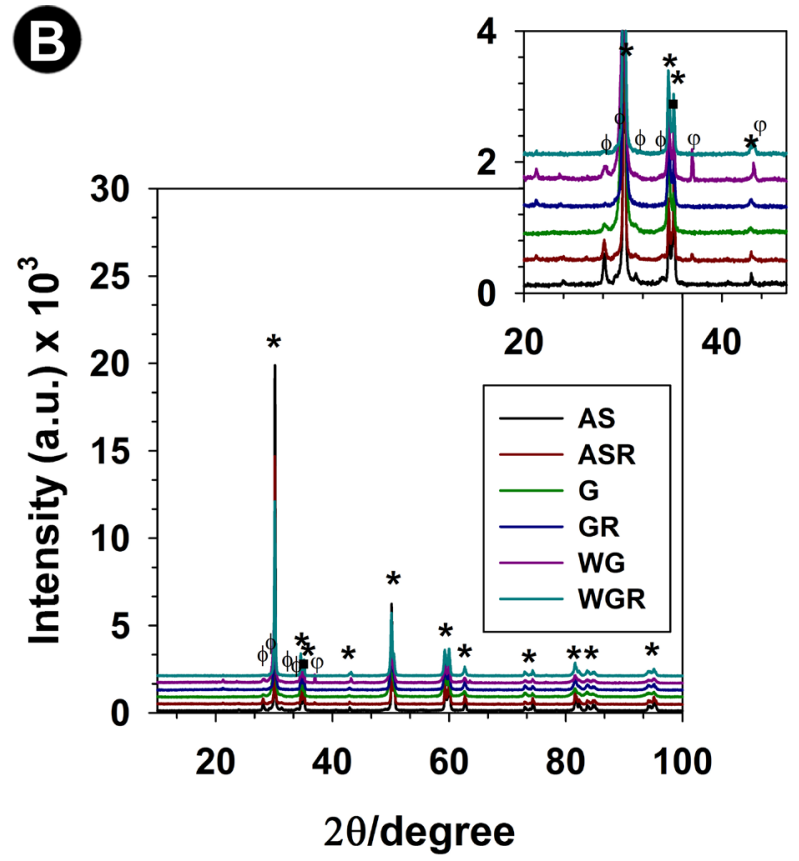


by the relief of compressive stresses on the material surface, reducing its mechanical strength (27). Although the heat treatment of the ground zirconia may reverse the phase from $m \rightarrow t$, the damage created in the surface could lead to failure by crack propagation or persistent major defects, since the flaws are not eliminated (7). However, this phase reversibility should not be confused as a mechanism for healing of the previously introduced flaws (28). Resintering only provides mechanical strength improvement to assintered specimens, but it may improve the aging resistance of the material, favoring its longevity, due to the decrease of the monoclinic phase content $(2,23)$.

Surface and thermal treatments may have opposite effects on the flexural strength of Y-TZP $(5,8,10,27)$. In the present study no significant differences were observed in the flexural fatigue limit among the resintered groups, although studies $(9,27)$ have found that heat treatment lowers the mechanical strength of zirconia. This may be attributed to the increase in the fatigue limit of the ASR specimens, considering the absence of effects on the strength of the ground samples (WGR and GR). A possible hypothesis for these findings is that the AS group presented an initial amount of monoclinic phase, as observed by the induced toughening mechanism by grinding. This result may be also explained by a molecular rearrangement and change on the chemical structure of the material induced by resintering. Since this was an isolated effect and considering the absence of detectable surface changes on the samples resintered or not, future investigations should clarify if this behavior is related to $\mathrm{m} \rightarrow \mathrm{t}$ transformation and/or associated to the molecular rearrangements.

From the results of this study, it was observed that resintering had no effect on the fatigue limit of the ground zirconia, regardless of water-cooling. Possibly, in these samples, the thermal effect of the resintering was superposed by the significant effect of "decomposition" of phases and/or molecular rearrangement produced by grinding. In turn, Wang et al. (8) observed changes in the properties of zirconia after heat treatment. According to those authors (8), thermal firing increased the Weibull modulus of zirconia. Based on this observation and on the results of the current study, it seems that resintering can influence the long-term behavior of mechanically treated zirconia. Furthermore, resintering seems to have a beneficial effect on the ground zirconia, since this step tended to increase the absolute values of flexural fatigue limit.

Among the limitations of this study are the use of geometrical specimens instead of anatomical ones, and no application of veneering porcelain over the zirconia. Additional studies including Weibull reliability and low temperature degradation analyses are required to evaluate the long-term behavior of Y-TZP under the tested conditions.

Based on the experimental design of this study, the following conclusions can be drawn: grinding with and without cooling increased the flexural fatigue limit of the non-resintered Y-TZP; resintering increased the fatigue limit of the as-sintered zirconia, while it did not change the fatigue strength of the ground groups; grinding changed the surface topography, forming evident grooves on the zirconia surface, while resintering and cyclic loading seemed not to be able to modify its surface feature; in general, grinding and resintering decreased or zeroed the monoclinic phase content.

\section{Resumo}

Este estudo avaliou o efeito de protocolos de desgaste e ressinterização no limite de fadiga flexural e na caracterização da superfície da zircônia Lava $^{\mathrm{TM}}$. Corpos-de-prova em forma de barra $(20 \times 4,0 \times 1,2 \mathrm{~mm}, \mathrm{n}=40$; $20 \times 4,0 \times 1,5 \mathrm{~mm}, \mathrm{n}=80$ ) foram obtidos. Metade das barras com menor altura $(1,2 \mathrm{~mm})$ constituiu o grupo controle (AS), enquanto as de maior altura $(1,5 \mathrm{~mm})$ foram desgastadas com fresas diamantadas com (WG) ou sem $(\mathrm{G})$ irrigação. A outra metade dos corpos-de-prova de menor altura e metade dos desgastados foram ressinterizadas $\left(1000{ }^{\circ} \mathrm{C}, 30\right.$ min), obtendo-se os grupos ASR, WGR e GR. 0 limite de fadiga (500.000 ciclos, $10 \mathrm{~Hz}$ ) foi avaliado pelo método de escada em dispositivo de flexão em 4 pontos. Os dados foram analisados pelos testes ANOVA a dois fatores e Tukey $(\alpha=0,05)$. A topografia de superficie $(n=3)$ e área de fratura $(n=3)$ foram avaliadas por MEV. Os dados de difração de raios-X $(n=1)$ foram analisados pelo refinamento de Rietveld. ANOVA revelou diferenças significantes $(p<0,001)$ para desgaste, ressinterização e interação entre os fatores. 0 desgaste aumentou o limite de fadiga para os grupos não ressinterizados. Não houve diferença significante entre os grupos ressinterizados. A ressinterização aumentou o limite de fadiga somente para o grupo AS. Ambos os protocolos criaram riscos evidentes na superfície da zircônia. As falhas iniciaram sempre no lado de tração. A porcentagem de fase monoclínica foi: AS (8.6), ASR (1.2), G (1.8), GR (0.0), WG (8.2), WGR (0.0) antes e AS (7.4), ASR (6.5), G (3.2), GR (0.2), WG (4.6), WGR (1.1) após a ciclagem. 0 desgaste aumentou o limite de fadiga da zircônia não ressinterizada e formou ranhuras evidentes na sua superfície. A ressinterização promoveu aumento significativo no limite de fadiga somente para o grupo controle. Em geral, o desgaste e a ressinterização diminuiram ou anularam o conteúdo de fase monoclínica.

\section{References}

1. Kosmac T, Oblak C, Jevnikar P, Funduk N, Marion L. The effect of surface grinding and sandblasting on flexural strength and reliability of Y-TZP zirconia ceramic. Dental Materials 1999;15:426-433.

2. Kosmac T, Oblak C, Jevnikar P, Funduk N, Marion L. Strength and reliability of surface treated Y-TZP dental ceramics. J Biomed Mater Res 2000;53:304-313.

3. Canneto JJ, Cattani-Lorente $M$, Durual $S$, Wiskott AH, Scherrer SS. Grinding damage assessment on four high-strength ceramics. Dent Mater 2016;32:171-182.

4. Swain MV. Limitation of maximum strength of zirconia-toughened ceramics by transformation toughening increment. J Am Ceramic Soc 1985;68:C97-C99.

5. Iserı U, Özkurt Z, Kazazoglu E; Davut Küçükoglu. Influence of grinding procedures on the flexural strength of zirconia ceramics. Braz Dent J 2010;21:528-532. 
6. Luthardt RG, Holzhüter M, Sandkuhl O, Herold V, Schnapp JD, Kuhlisch E, Walter M. Reliability and properties of ground Y-TZP-zirconia ceramics. J Dent Res 2002;81:487-491.

7. Denry IL, Holloway JA. Microstructural and crystallographic surface changes after grinding zirconia-based dental ceramics. J Biomed Mater Res B Appl Biomater 2006;76:440-448.

8. Wang $\mathrm{H}$, Aboushelib MN, Feilzer AJ. Strength influencing variables on CAD/CAM zirconia frameworks. Dent Mater 2008;24:633-638.

9. Sato H, Yamada K, Pezzotti G, Nawa M, Ban S. Mechanical properties of dental zirconia ceramics changed with sandblasting and heat treatment. Dent Mater J 2008;27:408-414.

10. Guess PC, Zavanelli RA, Silva NR, Bonfante EA, Coelho PG, Thompson VP. Monolithic CAD/CAM lithium disilicate versus veneered Y-TZP crowns: comparison of failure modes and reliability after fatigue. Int J Prosthodont 2010;23:434-442.

11. Takano T, Tasaka A, Yoshinari M, Sakurai K. Fatigue strength of Ce-TZP/ Al203 nanocomposite with different surfaces. J Dent Res 2012;91:800804.

12. Aboushelib MN, Wang H, Kleverlaan CJ, Feilzer AJ. Fatigue behavior of zirconia under different loading conditions. Dent Mater 2016;32:915920.

13. Amaral $M$, Cesar PF, Bottino MA, Lohbauer U, Valandro LF. Fatigue behavior of Y-TZP ceramic after surface treatments. J Mech Behav Biomed Mater 2016;57:149-156.

14. Fraga $\mathrm{S}$, Pereira GK, Freitas M, Kleverlaan CJ, Valandro LF, May LG. Loading frequencies up to $20 \mathrm{~Hz}$ as an alternative to accelerate fatigue strength tests in a Y-TZP ceramic. J Mech Behav Biomed Mater 2016;61:79-86.

15. Pereira GK, Silvestri T, Amaral M, Rippe MP, Kleverlaan CJ, Valandro LF. Fatigue limit of polycrystalline zirconium oxide ceramics: Effect of grinding and low-temperature aging. J Mech Behav Biomed Mater 2016;61:45-54

16. Dixon WJ, Mood AM. A method for obtaining and analyzing sensitivity data. J Am Stat Assoc 1948;43:109-126.

17. Chevalier J, Loh J, Gremillard L, Meille S, Adolfson E. Low-temperature degradation in zirconia with a porous surface. Acta Biomater 2011;7:2986-2993.

18. International Standard Organization. ISO TR 6872:1997. Dentistry Ceramic Materials. Geneva: ISO. 1997. Available at: http://www.iso.ch/ iso.ch/iso/en/prods-services/ISOstore/store.html

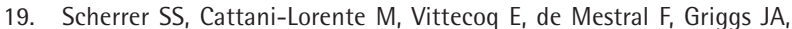
Wiskott HW. Fatigue behavior in water of Y-TZP zirconia ceramics after abrasion with $30 \mu \mathrm{m}$ silica-coated alumina particles. J Prosthet Dent 2011;105:217-226.

20. Collins JA. Failure of materials in mechanical design: analysis, prediction, prevention. In: Fatigue testing procedures and statistical interpretation of data. New York: John Wiley and Sons; 1993. p.383387.

21. Vergani CE, Seó RS, Reis JM, Giampaolo ET, Pavarina AC, Machado AL. Effect of water storage on the shear strength and fatigue limit of the reline resin bond to denture base resins. J Adhes Dent 2010;12:319-327.

22. Rietveld HM. A profile refinement method for nuclear and magnetic structures. J Appl Crystallogr 1969;2:65-71.

23. Kim JW, Covel NS, Guess PC, Rekow ED. Concerns of hydrothermal degradation in CAD/CAM zirconia. J Dent Res 2010;89:91-95.

24. Manicone PF, Rossi lommetti P, Raffaelli L. An overview of zirconia ceramics: basic properties and clinical applications. J Dent 2007;35:819-826.

25. Mochales $C$, Maerten $A$, Rack $A$, Cloetens $P$, Mueller WD, Zaslansky $P$, et al.. Monoclinic phase transformations of zirconia-based dental prostheses, induced by clinically practised surface manipulations. Acta Biomater 2011;7:2994-3002.

26. Duclos R. Direct observation of grain rearrangement during superplastic creep of a fine-grained zirconia. J Eur Ceram Soc 2004;24:3103-3110.

27. Guazzato M, Quach L, Albakry M, Swain MV. Influence of surface and heat treatments on the flexural strength of Y-TZP dental ceramic. J Dent 2005;33:9-18.

28. Denry I, Kelly JR. State of the art of zirconia for dental applications. Dent Mater 2008;24:299-307.

29. Amaral M, Valandro LF, Bottino MA, Souza RO. Low-temperature degradation of a Y-TZP ceramic after surface treatments. J Biomed Mater Res B Appl Biomater 2013;101:1387-1392.

Received November 6, 2015 Accepted May 9, 2016 